\title{
ЕМПІРИЧНІ ІНДИКАТОРИ ВПЛИВУ ПЕРФЕКЦІОНІЗМУ НА ПРОФЕСІЙНУ ІДЕНТИЧНІСТЬ ОФІЦЕРІВ
}

\section{Кузіна Вікторія Дмитрівна}

Науковий кореспондент Інституту психології імені Г.С. Костюка Національної академії педагогічних наук України, м. Київ (Украӥна)

\begin{abstract}
Анотація. Стаття присвячена висвітленню проблеми емпіричних індикаторів перфекціонізму як чинника розвитку професійної ідентичності офічерів Збройних Сил Украӥни. За результатами емпіричного дослідження встановлено групи офіцерів з різним рівнем прояву перфекціонізму: 1 група з високим рівнем, 2 група - з середнім, 3 група - з низьким. Для офіцерів 1 групи найбільш виразними є дифузний стиль професійної ідентичності (прийняття рімень на ходу, відкладання на невизначений час) та в меншому ступені нормативний стиль (прагнення слідувати традиціям, груповим нормам, соиіально бажаним варіантам рімення). Для офіцерів 2 групи - інформаційний (прагнення отримувати максимум інформації в ситуації наявного вибору, важливість мети для себе) та нормативний стилі, а для 3 групи - інформаційний стиль професійної ідентичності у поєднанні з високою сталістю вибудовування поведінки у професійному середовищі.
\end{abstract}

Ключові слова: перфекиіонізм, професійна ідентичність, офіцеер, особливі умови, військово-професійна діяльність.

Актуальність дослідження. Професійне становлення сучасного офіцера супроводжується зміною уявлень про себе, своє місце в професійному та соціальному світі - набуттям професійної ідентичності, професійною самоідентифікацією його особистості. Професійну ідентичність офіцера визначено як багатовимірний інтегративний психологічний феномен, що є результатом когнітивно-емоці- йно-поведінкового процесу ототожнення себе 3 професією офіцера і військово-професійним середовищем, що веде до самостійного вибудовування свого військово-професійного майбутнього та передбачає високу готовність смислових і регуляторних основ поведінки; здійснення особистісного, інструментального i ситуативного самовизначення (набуття досвіду); інтеграцію у військово-професійне сере- 
довище; формування і рефлексію уявлення про себе як офіцера.

Професійна ідентичність формується у процесі професійного розвитку та є одним із важливих показників становлення особистості військового професіонала як суб'єкта військово-професійної діяльності й більш повно розкривається в досягненні професійної суб' єктної позиції, що характеризує його тотожність, визначеність і цілісність.

Перфекціонізм позначається на результатах вибудовування ним військовопрофесійного майбутнього у процесі набуття професійної ідентичності. Такий вплив відображатиметься в уявленнях офіцера про особливості військово-професійного середовища, усвідомленні себе його членом на основі професійно-диференційованих ознак, що склалися; позначатиметься на особливостях формування само-оцінки офіцера як професіонала, оцінці ним своєї і чужих професійних груп, самоставленні до себе як професіонала, ставленні до своєї і чужих професійних груп відповідно; буде формувати відповідну цим позиціям систему стосунків і дій в різних ситуаціях професійної взаємодії (функціональнорольову поведінку).

Мета статті полягає у визначенні емпіричних індикаторів впливу перфекціонізму на професійну ідентичність офіцерів як чинників їх професійного становлення та виконання завдань за призначенням в особливих умовах військово-професійної діяльності.

\section{Виклад основного матеріалу дослі-} дження. Як показали теоретичні дослідження феномену перфекціонізму у офіцерів, його доцільно розглядати через багатовимірний особистісний конструкт, що поєднує в собі індивідуально-психологічні якості та особистісні характеристики, детермінуючі слідувати надмірно високим стандартам, прагнути до досконалості й встановлювати високі особисті стереотипи, доводити результати військовопрофесійної діяльності до відповідності найвищим еталонам. Він може проявлятися у формі ірраціональних переконань або дисфункційних установок, концентрації на реальних і минулих помилках, схильності до генералізації решти життєвих стандартів.

Для діагностики прояву перфекціонізму у досліджуваних офіцерів використано методики, що дозволили виявити особливості впливу перфекціонізму на професійну ідентичність офіцерів. Особистісна діагностична шкала «Багатовимірна шкала перфекціонізму» П. Л. Х'юїта і Г. Л. Флетта (Multidimensional perfectionism scale, MPS), розроблена канадськими ученими П. Л. Х'юїтом і Г. Л. Флеттом [5], застосовувалася нами для дослідження рівня прояву перфекціонізму у досліджуваних офіцерів і визначення характеру співвідношення його складових у цілісному профілі. Адаптація опитувальника була представлена I. I. Грачовою [2]. На основі MPS в рамках продовження досліджень перфекціоністської тенденції особистості П. Л. Х’юїттом була ро- 
зроблена єдина на сьогоднішній день шкала перфекціоністської самопрезентації (Perfectionistic Self-Presentation) [4]. Оригінальна модель перфекціоністської самопрезентації була покладена П. Л. Х’юїттом в основу створення «Шкали перфекціоністської самопрезентації», що застосовувалася нами в адаптації О. А. Золотарьової [3].

Дослідження професійної ідентичності офіцерів проводилося за допомогою «Опитувальника стилів ідентичності» М. Берзонскі в адаптації О. П. Белинської, I. Д. Броніна [1]. Дана методика дозволила виявити як досліджувані застосовують релевантну до ідентичності інформацію через виокремлення трьох стилів ідентичності: інформаційного, нормативного та дифузного. Вибірку досліджуваних склали 120 військовослужбовців - офіцерів, серед яких $88 \%$ чоловіків, 12\% жінок. Середній вік досліджуваних 35,9 років. Отримані результати емпіричного дослідження оброблялися за допомогою пакетів програм обробки статистичних даних: Microsoft Office Excel 2007, SPSS - 21.0.

\section{Аналіз результатів емпіричного дос-} лідження. Результати проведеного емпіричного дослідження дали змогу визначити психологічні аспекти впливу змістових характеристик перфекціонізму офіцерів на розвиток стильових особливостей їх професійної ідентичності.

Дослідження показників перфекціонізмy

офіцерів за опитувальником

«Багатовимірна

шкала

перфекціонізму»

П. Л. Х'юїта і Г. Л. Флетта дозволило визначити співвідношення його складових у цілісному профілі. При цьому нами було визначено групи офіцерів з різним рівнем прояву перфекціонізму: 1 група 3 високим рівнем (ВР) - 31 особа $(22,5 \%), 2$ група з середнім (СР) - 64 осіб (46,4\%), 3 група з низьким (НР) - 43 особи $(31,2 \%)$ (рис. 1$)$.

У 1 групу з високим (вищим за середній) рівнем перфекціонізму були віднесені

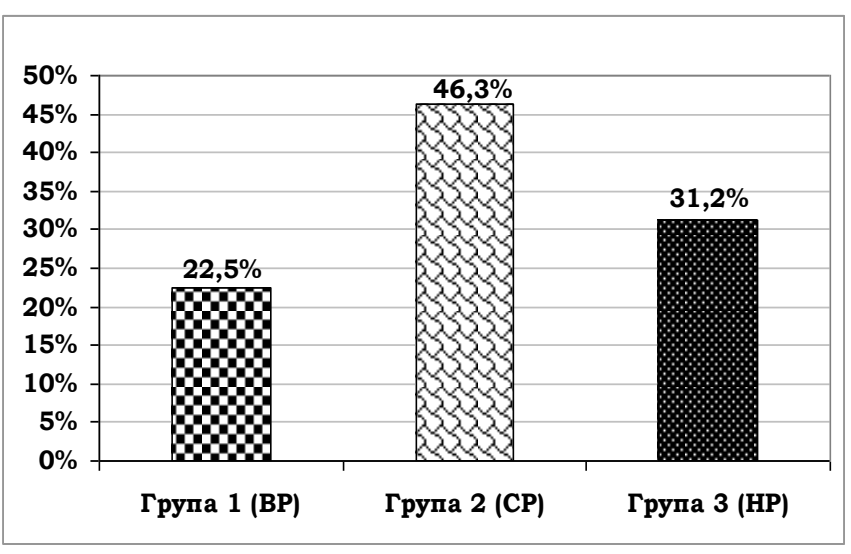

\section{Рис. 1. Розподіл офіцерів за рівнями прояву перфекціонізму}

особи, що набрали від 204 до 249 балів за інтегральним рівнем перфекціонізму. У 2 групу iз середнім рівнем перфекціонізму ввійшли досліджувані, які набрали сумарний бал у межах від 160 до 204. У 3 групу із низьким рівнем перфекціонізму увійшли досліджувані 3 низьким (нижчим за середній) рівнем перфекціонізму, які набрали в сумі по шкалі від 129 до 160 балів (табл. 1). 


\section{Індивідуальні профілі перфекціонізму офіцерів}

\begin{tabular}{|c|c|c|c|c|c|c|c|c|}
\hline \multirow{2}{*}{ № } & \multirow{2}{*}{\multicolumn{2}{|c|}{ Шкала }} & \multirow{2}{*}{$\begin{array}{c}\text { Група } 1 \\
\text { (ВР) }\end{array}$} & \multirow{2}{*}{$\begin{array}{c}\text { Група } 2 \\
(\mathrm{CP})\end{array}$} & \multirow{2}{*}{$\begin{array}{c}\text { Група } 3 \\
(\mathrm{HP})\end{array}$} & \multicolumn{3}{|c|}{ Відмінності між групами } \\
\hline & & & & & & $\mathrm{p}(1,2)$ & $\mathrm{p}(2,3)$ & $\mathrm{p}(1,3)$ \\
\hline 1 & \multicolumn{2}{|c|}{$\begin{array}{l}\text { Перфекціонізм, орієн- } \\
\text { тований на себе }\end{array}$} & $73,4 \pm 9,3$ & $69,7 \pm 9,8$ & $40,8 \pm 6,2$ & - & $\mathrm{p} \leq 0,01$ & $\mathrm{p} \leq 0,01$ \\
\hline 2 & \multicolumn{2}{|c|}{$\begin{array}{l}\text { Перфекціонізм, адре- } \\
\text { сований іншим }\end{array}$} & $91,2 \pm 12,5$ & $63,6 \pm 7,7$ & $43,4 \pm 5,3$ & $\mathrm{p} \leq 0,01$ & $\mathrm{p} \leq 0,01$ & $\mathrm{p} \leq 0,01$ \\
\hline 3 & \multicolumn{2}{|c|}{$\begin{array}{l}\text { Соціально обумовле- } \\
\text { ний перфекціонізм }\end{array}$} & $67,2 \pm 8,3$ & $52,3 \pm 7,1$ & $54,2 \pm 6,5$ & $\mathrm{p} \leq 0,01$ & - & $\mathrm{p} \leq 0,05$ \\
\hline 4 & \multicolumn{2}{|c|}{$\begin{array}{l}\text { Інтегральний показ- } \\
\text { ник }\end{array}$} & $\begin{array}{c}231,8 \pm 18 \\
5\end{array}$ & $\begin{array}{c}185,6 \pm 19 \\
2\end{array}$ & $\begin{array}{c}138,4 \pm 17 \\
5\end{array}$ & $\mathrm{p} \leq 0,01$ & $\mathrm{p} \leq 0,01$ & $\mathrm{p} \leq 0,01$ \\
\hline \multirow{3}{*}{\multicolumn{2}{|c|}{$\begin{array}{l}\text { Відмінності в } \\
\text { межах групи }\end{array}$}} & $\mathrm{p}(1,2)$ & $\mathrm{p} \leq 0,01$ & $\mathrm{p} \leq 0,05$ & - & & & \\
\hline & & $\mathrm{p}(2,3)$ & $\mathrm{p} \leq 0,01$ & $\mathrm{p} \leq 0,05$ & $\mathrm{p} \leq 0,01$ & & & \\
\hline & & $\mathrm{p}(1,3)$ & $\mathrm{p} \leq 0,05$ & $\mathrm{p} \leq 0,01$ & $\mathrm{p} \leq 0,01$ & & & \\
\hline
\end{tabular}

\section{Примітка: $p$ - рівень значущості відмінностей за t-критерієм Стьюдента}

До 1 групи з високим рівнем перфекціонізму увійшла найменша кількість досліджуваних офіцерів $(22,5 \%) \quad 3$ показником $231,8 \pm 18,5$ балів, для яких характерні найбільш виразні особистісні стандарти, вимогливість до себе, орієнтація на «найбільш успішних» колег по службі, постійне порівняння себе з ними, фіксація уваги на власних невдачах і помилках. У 2 групі офіцерів з середнім рівнем перфекціонізму (46,4\%) з показником $185,6 \pm 19,2$ балів зазначені характеристики проявляються в меншому ступені, втім вони також можуть відчувати певні сумніви та вагання при виконанні завдань у повсякденній діяльності, чутливі до критики командирів та колег, менше відчувають задоволення від здобутих результатів власної військовопрофесійної діяльності. У 3 групі офіцерів 3 низьким рівнем перфекціонізму $(31,2 \%)$ та показником 138,4 $\pm 17,5$ балів зазначені якості проявляються найменше. Отримані показники по групах значущо відрізняються між собою за t-критерієм Стьюдента $(\mathrm{p} \leq 0,01)$.

Разом $з$ тим слід зазначити, що показники прояву перфекціонізму за окремими шкалами мають специфічні співвідношення та не всі значущо відрізняються як в межах однієї групи так і між групами досліджуваних офіцерів (табл. 1., рис. 2).

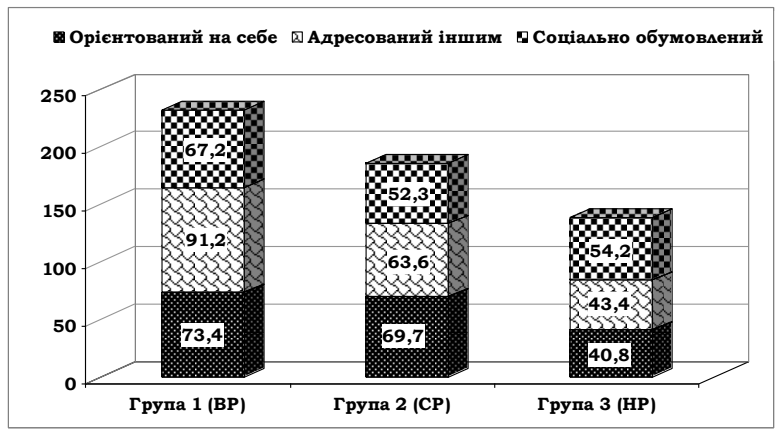

Рис. 2. Співвідношення профілів перфекціонізму у офіцерів 
Так, за шкалою перфекціонізму, орієнтованого на себе у досліджуваних 1 групи 3 високим рівнем $(73,4 \pm 9,3$ балів) не виявлені значущі відмінності від 2 групи із середнім

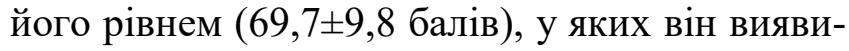
ся найвищим серед інших шкал. Офіцери 3 групи з низьким рівнем перфекціонізму, орієнтованого на себе $(40,8 \pm 6,2)$, також показали значущі відмінності від групи із середнім рівнем ( $\leq \leq 0,01)$. Такі результати свідчать, що при високому рівні перфекціонізму, орієнтованого на себе, офіцерам 2 групи більш властиво пред’являти надзвичайно високі вимоги до себе, відповідно, чим нижче його рівень тим нижче і вимоги, що пред'являють до себе офіцери.

За шкалою перфекціонізму, адресованого іншим у досліджуваних 1 групи з високим рівнем $(91,2 \pm 12,5$ балів) виявлені значущі відмінності $(\mathrm{p} \leq 0,01)$ від 2 групи офіцерів із середнім його рівнем $(63,6 \pm 7,7$ балів). Офіцери 3 групи з низьким рівнем перфекціонізму, адресованого іншим $(43,4 \pm 5,3)$ показали значущі відмінності від 2 групи із середнім рівнем $(\mathrm{p} \leq 0,01)$. Такі результати свідчать, що при високому рівні перфекціонізму, адресованого іншим, офіцерам 1 групи у більшому ступені за інших властиво висувати високі вимоги до навколишніх. Офіцери 3 групи з низьким рівнем мають нижчі вимоги до оточення та колег серед досліджуваних груп.

За шкалою соціально обумовленого перфекціонізму у досліджуваних офіцерів 1 групи 3 високим рівнем (67,2 $\pm 8,3$ балів) вияв- лені значущі відмінності $(\mathrm{p} \leq 0,01)$ від 2 групи iз середнім його рівнем (52,3 $\pm 7,1$ балів). А офіцери 3 групи з низьким рівнем інтегрального перфекціонізму $(54,2 \pm 6,5)$ не показали значущі відмінності від 2 групи із середнім інтегральним рівнем перфекціонізму ( $\mathrm{p} \geq 0,05)$. Такі результати дозволяють припустити, що представники 1 групи з високим рівнем інтегрального перфекціонізму схильні розцінювати вимоги, що висуваються до них навколишніми, колегами як завищені й нереалістичні. А у представників 2 та 3 груп із середнім та низьким рівнями інтегрального показника така тенденція виражена значно менше.

Результати дослідження також показали, що перфекціонізм, орієнтований на себе, 3 поміж інших шкал найбільш виразний у офіцерів 2 групи 3 середнім рівнем прояву інтегрального показника $(69,7 \pm 9,8)$. При цьому в цій групі офіцерів перфекціонізм, адресований іншим $(63,6 \pm 7,7)$ значущо відрізняється від соціально обумовленого перфекціонізму $(63,6 \pm 7,1, p \leq 0,05)$, що свідчить про переважання у цій групі досліджуваних тенденції пред'являти більш високі вимоги до себе, ніж до оточення. Тенденція висувати більші вимоги до інших найбільш виразна у офіцерів 1 групи 3 високим рівнем інтегрального показника $(91,2 \pm 12,5)$, порівняно 3 рештою показників $(\mathrm{p} \leq 0,01)$. У офіцерів 3 групи з низьким загальним рівнем перфекціонізму найбільш виразним виявився соціально обумовлений перфекціонізм $(54,2 \pm 6,5, \mathrm{p} \leq 0,01)$, як тенденція розці- 
нювати вимоги, що висуваються до них начальниками та колегами як завищені. При цьому показники перфекціонізму, орієнтованого на себе та адресованого іншим у цій групі офіцерів значущо не відрізняються $(\mathrm{p} \geq 0,05)$.

Такі результати нерівномірного співвідношення складових компонентів перфекціонізму підтверджують позицію, що вони можуть бути різнодиференційованими. Таким чином, при однаковому рівні виразності цієї риси можуть складатися різні профілі його компонентів (перфекціонізму, орієнтованого на себе, на інших і соціально обумовленого перфекціонізму).

Дослідження показників перфекціоністської самопрезентації офіцерів за «Шкалою перфекціоністської самопрезентаиії» в адаnтачіï О.А. Золотарьової дозволило виявити їх структуру в досліджуваних групах офіцерів. групі офіцерів $(47,2 \pm 9,8)$ та $(45,5 \pm 8,7)$, що показує високі прагнення офіцера створювати образ себе з високо розвиненими здібностями, з бездоганною репутацією, соціальною компетентністю і успіхом у військово-професійному середовищі. У 3 групі офіцери в значно меншому ступені презентують ці перфекціоністські характеристики $(40,3 \pm 7,5, p \leq 0,01)$.

За показниками шкали «поведінковий непрояв недосконалості» найвищі показники у 1 та 2 групах офіцерів $(46,5 \pm 8,4$ та 45,2 28,9 відповідно), що показує їх вищу залежність від думки колег та керівництва за офіцерів 3 групи $(42,1 \pm 9,3, \mathrm{p} \leq 0,05)$, а також вищу чутливість до критики, прагнення до уникнення соціальних ситуацій у військово-професійній діяльності, в яких поведінка може бути в центрі уваги оточення.

Таблиия 2

\section{Структура перфекціоністської самопрезентації офіцерів}

\begin{tabular}{|c|l|c|c|c|c|c|c|}
\hline № & \multicolumn{1}{|c|}{ Шкала } & $\begin{array}{c}\text { Група 1 } \\
\text { (ВР) }\end{array}$ & $\begin{array}{c}\text { Група 2 } \\
\text { (СР) }\end{array}$ & $\begin{array}{c}\text { Група 3 } \\
\text { (НР) }\end{array}$ & $\mathrm{p}(1,2)$ & $\mathrm{p}(2,3)$ & $\mathrm{p}(1,3)$ \\
\hline 1. & $\begin{array}{l}\text { Демонстрація доскона- } \\
\text { лості }\end{array}$ & $47,2 \pm 9,8$ & $45,5 \pm 8,7$ & $40,3 \pm 7,5$ & - & $\mathrm{p} \leq 0,05$ & $\mathrm{p} \leq 0,01$ \\
\hline 2. & $\begin{array}{l}\text { Поведінковий непрояв } \\
\text { недосконалості }\end{array}$ & $46,5 \pm 8,4$ & $42,1 \pm 9,3$ & $45,2 \pm 8,9$ & $\mathrm{p} \leq 0,05$ & $\mathrm{p} \leq 0,05$ & - \\
\hline 3. & $\begin{array}{l}\text { Вербальний непрояв } \\
\text { недосконалості }\end{array}$ & $25,9 \pm 5,6$ & $26,4 \pm 6,9$ & $27,3 \pm 7,2$ & - & - & $\mathrm{p} \leq 0,05$ \\
\hline
\end{tabular}

Примітка: $p$ - рівень значущості відмінностей за t-критерієм Стьюдента

Отримані результати дослідження показали, що за шкалою «демонстрація досконалості» найбільш виразними є показники у 1
За шкалою «вербальний непрояв недосконалості» найбільш виразний прояв показників у офіцерів 3 групи $(27,3 \pm 7,2, p \leq 0,05)$ порів- 
няно 31 та 2 групами, що відображає схильність до уникнення ситуацій, в яких власні недоліки можуть стати мішенню для обговорення серед інших військовослужбовців.

Отже, результати показують, що для офіцерів 1 групи з високим загальним рівнем перфекціонізму суттєвими його самопрезентаціями є демонстрація досконалості (прагнення видатися бездоганним в очах навколишніх, викликати своєю досконалістю їх повагу) та поведінковий непрояв недосконалості (прагнення поводитися таким чином, щоб приховати власну недосконалість від інших). Для офіцерів 2 групи - з середнім рівнем перфекціонізму більш виразна самопрезентація демонстрації досконалості, а для 3 групи - 3 низьким рівнем - поведінковий непрояв недосконалості та вербальний непрояв недосконалості (прагнення уникнути визнання власної недосконалості перед іншими).

Стилі професійної ідентичності офіцерів вивчалися за допомогою «Опитувальника стилів ідентичності» М. Берзонскі в адаптації О.П. Белинської, І.Д. Броніна, результати яких наведено в табл. 3.

Як показали результати дослідження, інформаційний стиль ідентичності у офіцерів 1 групи проявився на середньому рівні $(17,5 \pm 4,8)$, проте у офіцерів 2 групи характеристики інформаційного стилю виявлені високого рівня, що значно відрізняються від 1 групи $(19,4 \pm 5,2, p \leq 0,05)$. Найвищі показники за даним стилем у офіцерів 3 групи $(21,3 \pm 5,9$, $\mathrm{p} \leq 0,01)$, що свідчить про їх прагнення в більшій мірі отримувати максимум інформації в ситуації наявного вибору, перш ніж прийняти рішення про важливість мети для себе, значущості тієї чи іншої позиції та цінності, того чи іншого напрямку власного розвитку порівняно 3 офіцерами 1 та 2 груп.

Нормативний стиль виявися найбільш виразним у офіцерів 1 групи $(18,5 \pm 6,4)$, що значно не відрізняється від офіцерів 2 групи $(17,8 \pm 6,6)$ й в обох групах розвинений на достатньо високому рівні. Офіцери 3 групи показали його середній рівень розвитку $(16,7 \pm 5,5, \mathrm{p} \leq 0,05)$, що значно нижче за 1 та 2 групу. Враховуючи показники інформаційного стилю це може свідчити про виразне прагнення офіцерів 1 групи слідувати сімейним

Таблиця 3

\section{Стилі професійної ідентичності офіцерів}

\begin{tabular}{|c|l|c|c|c|c|c|c|}
\hline № & \multicolumn{1}{|c|}{ Шкала } & $\begin{array}{c}\text { Група 1 } \\
\text { (ВР) }\end{array}$ & $\begin{array}{c}\text { Група 2 } \\
(\text { СР) }\end{array}$ & $\begin{array}{c}\text { Група 3 } \\
(\text { НР })\end{array}$ & $\mathrm{p}(1,2)$ & $\mathrm{p}(2,3)$ & $\mathrm{p}(1,3)$ \\
\hline 1. & Інформаційний стиль & $17,5 \pm 4,8$ & $19,4 \pm 5,2$ & $21,3 \pm 5,9$ & $\mathrm{p} \leq 0,05$ & $\mathrm{p} \leq 0,05$ & $\mathrm{p} \leq 0,01$ \\
\hline 2. & Нормативний стиль & $18,5 \pm 6,4$ & $17,8 \pm 6,6$ & $16,7 \pm 5,5$ & - & $\mathrm{p} \leq 0,05$ & - \\
\hline 3. & Дифузний стиль & $24,3 \pm 7,2$ & $12,5 \pm 4,9$ & $11,8 \pm 5,1$ & $\mathrm{p} \leq 0,01$ & - & $\mathrm{p} \leq 0,01$ \\
\hline 4. & Шкала прихильності & $16,6 \pm 4,8$ & $19,2 \pm 5,9$ & $20,1 \pm 6,1$ & $\mathrm{p} \leq 0,01$ & - & $\mathrm{p} \leq 0,01$ \\
\hline
\end{tabular}

Примітка: p - рівень значущзості відмінностей за t-критерієм Стьюдента 
традиціям, соціальним (груповим) нормам, готовим та соціально бажаним варіантам рішення у професійній діяльності.

Результати за шкалою дифузний стиль показують виразний його розвиток у офіцерів 1 групи $(24,3 \pm 7,2, p \leq 0,01)$, порівняно 3 рештою досліджуваних, що свідчить про прийняття ними рішень у професійних ситуаціях на ходу, а також їх відкладання на невизначений час. Така лінія поведінки майже не характерна для 2 та 3 груп офіцерів, у яких цей стиль професійної ідентичності розвинений на значно нижчому рівні $(12,5 \pm 4,9$ та $11,8 \pm 5,1$ відповідно).

За шкалою прихильності, що відображає ступінь, в якій офіцери схильні дотримуватися своїх поглядів або, навпаки, постійно їх змінювати, найбільш виразними показники виявилися у офіцерів 2 та 3 груп $(19,2 \pm 5,9$ та

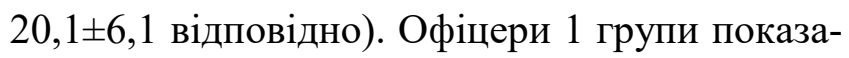
ли значно нижчі результати $(16,6 \pm 4,8, \mathrm{p} \leq 0,01)$ й здатність витримувати стабільну лінію поведінки відповідно.
Таким чином, для офіцерів 1 групи високим загальним рівнем перфекціонізму найбільш виразними є дифузний стиль професійної ідентичності (прийняття рішень на ходу, відкладання на невизначений час) та в меншому ступені нормативний стиль (прагнення слідувати традиціям, груповим нормам, соціально бажаним варіантам рішення). Для офіцерів 2 групи - 3 середнім рівнем перфекціонізму інформаційний (прагнення отримувати максимум інформації в ситуації наявного вибору, важливість мети для себе) та нормативний стилі, а для 3 групи - 3 низьким рівнем - інформаційний стиль професійної ідентичності у поєднанні $з$ високою сталістю вибудовування поведінки у професійному середовищі.

3 метою розкриття взаємозв'язку змістових характеристик перфекціонізму та професійної ідентичності офіцерів нами було застосовано кореляційний аналіз емпіричних результатів за шкалами застосованих у дослідженні психодіагностичних методик (табл. 4).

Таблиия 4 ті офіцерів $\left(r_{p}\right)$

\begin{tabular}{|l|c|c|c|}
\hline \multirow{2}{*}{$\begin{array}{c}\text { Показники перфекціонізму / професійної } \\
\text { ідентичності }\end{array}$} & \multicolumn{3}{|c|}{ Стилі професійної ідентичності } \\
\cline { 2 - 4 } & $\begin{array}{c}\text { Iнформаційний } \\
\text { стиль }\end{array}$ & $\begin{array}{c}\text { Нормативний } \\
\text { стиль }\end{array}$ & $\begin{array}{c}\text { Дифузний } \\
\text { стиль }\end{array}$ \\
\hline Перфекціонізм, орієнтований на себе & $0,506^{*}$ & $0,637^{* *}$ & - \\
\hline Перфекціонізм, адресований іншим & - & $0,548^{*}$ & $0,629^{* *}$ \\
\hline Соціально обумовлений перфекціонізм & $0,659^{* *}$ & - & - \\
\hline Інтегральний рівень перфекціонізму & - & $0,527^{*}$ & $0,625^{* *}$ \\
\hline Демонстрація досконалості & - & $0,581^{*}$ & $0,682^{* *}$ \\
\hline Поведінковий непрояв недосконалості & $0,622^{* *}$ & - & $0,518^{*}$ \\
\hline Вербальний непрояв недосконалості & $0,486^{*}$ & - & - \\
\hline
\end{tabular}


Результати кореляційного аналізу показали наявність значущих зв'язків між змістовими характеристиками перфекціонізму офіцерів та стильовими особливостями їх професійної ідентичності. Зокрема були виявлені:

- прямі значущі зв'язки інформаційного стилю професійної ідентичності та перфекціонізмом, орієнтованим на себе $(\mathrm{p} \leq 0,05)$, соціально обумовленим перфекціонізмом $(\mathrm{p} \leq 0,01)$, поведінковим непроявом недосконалості ( $\mathrm{p} \leq 0,01)$, вербальним непроявом недосконалості $(\mathrm{p} \leq 0,05)$;

- прямі значущі зв'язки нормативного стилю професійної ідентичності та перфекціонізмом, орієнтованим на себе $(\mathrm{p} \leq 0,01)$, перфекціонізмом, адресованим іншим $(\mathrm{p} \leq 0,05)$, інтегральним рівнем перфекціонізму $(\mathrm{p} \leq 0,05)$, демонстрацією досконалості $(\mathrm{p} \leq 0,05)$;

- прямі значущі зв'язки дифузного стилю професійної ідентичності та перфекціонізмом, адресованим іншим $(\mathrm{p} \leq 0,01)$, інтегральним рівнем перфекціонізму ( $\mathrm{p} \leq 0,01)$, демонстрацією досконалості $(\mathrm{p} \leq 0,01)$, поведінковим непроявом недосконалості $(\mathrm{p} \leq 0,05)$.

Висновки. Наведені прямі кореляційні зв'язки дозволяють припустити, що існує пряма залежність у розвитку пов'язаних якостей між собою, зокрема між рівнем розвитку перфекціонізму офіцерів та змістовими характеристиками їх професійної ідентичності. Так, високий рівень інтегрального перфекціонізму обумовлює розвиток дифузного стилю професійної ідентичності та в деякій мірі норматив- ного стилю, орієнтацію викликати своєю досконалістю повагу оточення та колег, що, на нашу думку, зміщує акцент з внутрішньої мотивації у діяльності на зовнішню. Тобто прагнення слідувати надмірно високим стандартам, встановлювати занадто високі особисті стереотипи досягнень заважатиме розвитку досягнутої професійної ідентичності особистості. Втім, можна також зазначити і про сприяння середнього та помірного рівнів перфекціонізму активізації механізмів розвитку професійної ідентичності (інформаційного стилю) через визначення своїх власних перспектив розвитку у професійному середовищі шляхом усвідомлення важливості поставлених цілей військово-професійної діяльності, зважування альтернатив у ситуації важливого вибору того чи іншого напрямку власного професійного розвитку.

\section{Перспектива подальших досліджень} полягає у виявленні психологічних особливостей динаміки перфекціонізму та професійної ідентичності офіцерів різних військових спеціальностей, особливості зміни перфекціонізму та професійної ідентичності у офіцерів, які брали участь в бойових діях.

\section{Перелік використаних джерел:}

1. Белинская Е. П. Адаптация русскоязычной версии опросника стилей идентичности М. Берзонски / Е. П. Белинская, И. Д. Бронин // Психологические исследования. - 2014. - Т.7. - №34. - С.12.

2. Грачева И. И. Адаптация методики «Многомерная 
шкала перфекционизма» П. Хьюитта и Г. Флетта / И. И. Грачева // Психологический журнал. - 2006. - Vol. 27, № 6. - С. 73-81.

3. Золотарева A. А. Адаптация методики «Шкала перфекционистской самопрезентации» П. Хьюитта / А. А. Золотарева // Психологический журнал. - 2011. - Т. 32, № 6. - С. 59-66.

4. Frost R. O. The dimensions of perfectionism / R. O. Frost et al. // Cognitive Therapy and Research. - 1990. Vol. 14, № 5. - P. 449-468.

5. Hewitt P. L. The Multidimensional Perfectionism Scale: Development and validation / P. L. Hewitt, G. L. Flett // Canad. Psychol. - 1989. - Vol. 30. - P. 103-109.

\section{References (Transliteration):}

1. Belinskaya E. P. \& Bronin I. D. (2014). Adaptatsiya russkoyazyichnoy versii oprosnika stiley identichnosti [Adaptation of the Russian-language version of the questionnaire of identity styles M. Berzonski]. Psihologicheskie issledovaniya - Psychological research, Vol. 7, 34, 12 [in Russian].

2. Gracheva I. I. (2006). Adaptatsiya metodiki «Mnogomernaya shkala perfektsionizma» P. Hyuitta i G. Fletta [Adaptation of the methodology «The Multidimensional Scale of Perfectionism» by P. Hewitt and G. Flett]. Psihologicheskiy zhurnal - Psychological journal, Vol. 27, 6, 73-81 [in Russian].

3. Zolotareva A. A. (2011). Adaptatsiya metodiki «Shkala perfektsionistskoy samoprezentatsii» P. Hyuitta [Adaptation of the methodology «Scale of perfectionist self -presentation» by P. Hewitt]. Psihologicheskiy zhurnal Psychological journal, Vol. 32, 6, 59-66 [in Russian].

4. Frost $R$. $O$. et al. (1990). The dimensions of perfectionism. Cognitive Therapy and Research. Vol. 14, 5, 449-468.

5. Hewitt P. L. \& Flett G. L. (1989). The Multidimensional Perfectionism Scale: Development and validation. Canad. Psychol. Vol. 30, 103-109.

\section{Kuzina Viktoria}

Science correspondent of G.S. Kostiuk Institute of Psychology of the National Academy of Educational Sciences of Ukraine, Kyiv (Ukraine)

\section{EMPIRIC INDICATORS OF PERFECTIONISM INFLUENCE ON THE PROFESSIONAL IDENTITY OF OFFICERS}

\section{ABSTRACT}

The article is devoted to the study of problem of empiric indicators of perfectionism as a factor of professional identity development of officers of the Armed Forces of Ukraine. As a result of empiric research the groups of officers are set with the different level of display of perfectionism: 1 group with a high level, 2 groups with middle, 3 groups - with low. Found out uneven correlation of constituents of perfectionism (oriented to itself, oriented on other and socially conditioned), that shows up in different expressiveness of separate components in types after the groups of investigated. To the officers 1 and 2 groups it is more peculiar to produce extraordinarily high demands to itself, however to a 1 group in a greater degree for other it is peculiar to pull out high demands to circumferential, they are inclined to consider requirements which are pulled out to them by colleagues as overpriced and unrealistic. Perfectionism, oriented to itself (from between other scales) most expressive for officers 2 groups which can produce higher requirements to itself, than to surroundings. For officers 3 groups socially conditioned perfectionism appeared most expressive, as a tendency to 
consider requirements which are pulled out to them by chiefs and colleagues as overpriced.

For the officers of a 1 group most expressive is diffuse style of professional identity (making decision in motion, laying on indefinite time) and in a less degree normative style (aspiration to follow traditions, group norms, socially desired variants of decision). For officers 2 groups - informative (aspiration to get maximum information in the situation of present choice, importance of purpose on your own) and normative styles, and for 3 groups is informative style of professional identity in combination with high constancy of lining up a conduct in a professional environment.

Discovered cross-correlation copulas show direct dependence between semantic descriptions of perfectionism and indexes of professional claim of officers and stylish features them professional identity.

Key words: perfectionism, professional identity, officer, special conditions, militaryprofessional activity.

\section{Кузина Виктория Дмитриевна}

Научный корреспондент Института психологии имени Г. С. Костюка Национальной академии педагогических наук Украины, г. Киев (Украина)

\section{ЭМПИРИЧЕСКИЕ ИНДИКАТОРЫ ВЛИЯНИЯ ПЕРФЕКЦИОНИЗМА НА ПРОФЕССИОНАЛЬНУЮ ИДЕНТИЧНОСТЬ ОФИЦЕРОВ}

ма как фактора развития профессиональной идентичности офицеров Вооруженных Сил Украины. По результатам эмпирического исследования установлены группы офицеров с разным уровнем проявления перфекционизма: 1 группа с высоким уровнем, 2 группа - со средним, 3 группа - с низким. Для офицеров 1 группы наиболее выразительным является диффузный стиль профессиональной идентичности (принятие решений на ходу, откладывание на неопределенное время) и в меньшей степени нормативный стиль (стремление следовать традициям, групповым нормам, социально желаемым вариантам решения). Для офицеров 2 группы - информационный (стремление получать максимум информации в ситуации имеющегося выбора, важность цели для себя) и нормативный стили, а для 3 группы - информационный стиль профессиональной идентичности в сочетании с высоким постоянством выстраивания поведения в профессиональной среде.

Ключевые слова: перфекционизм, профессиональная идентичность, офицер, особые условия, военно-профессиональная деятельность.
Аннотация. Статья посвящена проблеме эмпирических индикаторов перфекциониз-
Дата отримання статті: 14.10.2017

Дата рекомендації до друку: 21.10.2017 